\title{
INFORMATION AND COMMUNICATION EXPANSION IN THE BALKANS AS AN IMPLEMENT OF GEOPOLITICAL INFLUENCE
}

\begin{abstract}
Ivan V. Surma ${ }^{1}$
Abstract: Modern information and communication expansion is one of the instruments of geopolitical influence, which is used along with military and economic expansion to achieve dominance in a specific target region. The author, based on a systematic approach, attempts to explore the current state of the information and communication space of the Balkans.

The article considers the issue of information and communication expansion of Western countries in the Balkan political arena, with clearly defined goals pursued by the US and the EU, which do not always coincide. In recent years they have even come into a certain contradiction, especially since dissatisfaction with the European Union is ripening in the Balkans due to the EU's new approach in the form of "privileged partnership". It is shown that, on the one hand, the process of external acquisition by foreign actors of key mass media, Internet providers and mobile communications of the Balkan states is currently underway (ideally they are interested in establishing full control over the media and mobile communication systems of the Balkans). On the other hand, the thesis in the Western mass media that Russia systematically affects it, for which information campaigns allegedly have long been a habitual affair, blows onto the media space of the Balkan countries. Accordingly, the media very clearly follow the EU and NATO orders, that is, they work out the financing, demonizing Russia.

The author believes that the United States and the EU see their main task in the formation and education of a new generation of young analysts and experts who could defend the positions of Western countries and leading international organizations, explain to the population their advantages, and give favorable forecasts for them. Various structures, information and
\end{abstract}

\footnotetext{
${ }^{1}$ Head of the Department of public administration in foreign policy of the Diplomatic Academy of the Russian Ministry of Foreign Affairs, Ph.D.

Address: 53/2 str. Ostozhenka, Moscow, Russia, 119021.

E-mail: vsurma@gmail.com
} 
analytical centers, academies and institutes specially created for this purpose, as well as other Western foundations and non-governmental organizations (NGOs), were called upon to unite such experts, to form a pool from them. Non-governmental organizations (NGOs) as actors of information expansion today have a significant impact on the formation of the public and civil environment in the Balkan space. At the same time, the activities of many local and international non-governmental organizations, essentially financed by Western structures, often constitute interference in the domestic and foreign policy of the state and can be a threat to national and regional security. Based on the research materials of a number of scientists from Serbia and Bulgaria, the author emphasizes that in the current conditions, we can expect a further deepening of the split in the European Union itself on the main Balkan problems, as well as an increase in the attention of the capitals of the Balkan's countries to alternative integration projects, including with the participation of Russia, China, and other world powers. On the other hand, it can be said that the post-truth propagated by the Western media mainstream, nevertheless, cannot compete with reality. Therefore, the best way of information interaction and cooperation is not aggressive propaganda but joint practical activities in the humanitarian sphere and other areas of mutual interest to all parties.

Keywords: EU, Balkan, information expansion, mass-media, Russia, nongovernmental organizations, geopolitical influence.

Preface. Modern information and communication expansion is an instrument of geopolitical influence that is used along with military and economic expansion to achieve dominance in the target region. Therefore, speaking about the information and communication expansion of the West in the Balkans during the post-Soviet period, it is necessary to clearly define its goals pursued by the US and the EU, which do not always coincide and lately have even come into some sort of conflict with each other. At the first stage, the collapse of the USSR and the dissolution of the Warsaw Pact, the main goal of Western propaganda was "decommunization" of the Balkan countries, which had been previously within the Soviet Union's sphere of influence, in order to destroy the existing "pro-Soviet" political landscape (destruction of some states and creation of others on their ruins). And the West was at one in thinking of the necessity to implement this plan, which was demonstrated by the "humanitarian" NATO bombings of Yugoslavia (it should be noted that one of the priority targets of these bombings were 
radio and television centres) ${ }^{2}$. And when the NATO military bloc bombed the Radio Television of Serbia (RTS) in 1999, its arguments were clearly built on the simple fact that television inevitably spreads propaganda on behalf of its owner. Therefore, since its owner was a hostile state, and propaganda is an integral part of any war, NATO considered television to be a weapon in this war and, therefore, a legitimate target for attack. The tendencies and goals of Western propaganda after 1989 were perceived by most of the public in the Balkan countries as a "new interpretation of history." In fact, NATO did not collapse (unlike the Warsaw Pact), and the Western propaganda did not change its practices, except for its wording, which became an anti-Russian instead of anti-Soviet. The evident absence of an ideological basis in this propaganda shows that the Cold War is not ideological warfare, but rather a war for resources and against the Slavs as a cultural community. Later on, from the beginning of the 2000s, the information policy of the West in respect of the Balkans was still uniform - the main emphasis was made on the introduction of Western standards in modern media in the Balkan countries, on the creation of new national sources of information under the control of Western entities. These new Balkan mass media were supposed to counteract the "Russian information expansion", which increasingly frightened Western elites since the EU countries and then the United States began to lose their positions on the international stage. As the crisis of the West-centric world order escalated, which was accelerated by Donald Trump's rise to power, the contradictions between its pillars - the United States and the EU - began to grow, including in the Balkan region. Besides, currently, one can expect in the Balkans a deeper split within the European Union itself, in particular, between Paris and Berlin, as well as a shift in emphasis towards alternative integration processes in the Balkan countries, including those involving Russia, China and several other world powers. That is why this fact has been reflected today in the tasks that the EU leadership and the US leader are charging with their information policymakers. And the current situation around the

\footnotetext{
${ }^{2}$ On April 23, 1999, NATO missiles destroyed the Radio Television of Serbia (RTS) building, taking the lives of sixteen employees. On May 3, 1999, on world press freedom day, NATO will level another TV Studio in Yugoslavia, Radio-TV Novi Sad.
} 
informational influence and the general strategy of the Western nations aim to spur the maximum isolation of the Balkan and Eastern European countries from Russia, in order to hinder Russian integration and cultural influence since the role of the Russian language, Russian media landscape and Russian culture is still quite essential. All this predetermined the information expansion of the West in the region, which was put into practice under the slogan "transition from dictatorship to democracy" and gave rise to a whole series of 'colour revolutions' in the post-Soviet space or attempts to make them. Therefore, the West pays close attention to the formation of a beneficial information-communication and information-analytic landscape in the Balkans. Based on this, the United States and the EU see their main task in the formation and upbringing of a new generation of analysts and experts who could defend the positions of Western countries and leading international organizations, enlighten the public about their advantages, and make forecasts beneficial for them. Various entities were called upon to unite such experts to form a certain pool of them - different think tanks, academies and institutes specially created for these purposes, as well as other Western funds and non-governmental organizations (NGOs). However, the existence of NGOs sponsored by the West is not enough to achieve strategic goals, to build a certain ground for regional humanitarian and other kinds of intervention. To effectively manage this process, it is necessary to raise a local pro-Western "intellectual elite" since the opinions and judgements of local media personalities always inspire more confidence among the population than the speeches of foreign guests, and secondly, the activities of Western emissaries remain rather difficult in some countries due to the specifics and characteristics of their political construction.

\section{INFORMATION STRATEGY PURSUED BY THE EU IN THE BALKANS}

In September 2017, Jean-Claude Juncker delivered the report "On the State of the Union" and elaborated on a "new word" of Brussels as part of the certain propaganda campaign, which supposedly opened the doors of the EU to the states of the region. Later on, on February 6, 2018, the 
European Commission adopted the strategy "A credible outlook for enlargement of the EU and closer cooperation with the Western Balkans". However, let us take a closer look at the advantages the European Union is really offering to its potential and even "officially" recognized candidates (Albania, Macedonia, Serbia, Montenegro), and what it expects from them in return. Earlier at the meeting of the European Council (2003) in Thessaloniki, a paradigm was proposed concerning a special European path for the countries of the Western Balkans which are in fact already surrounded by the EU countries and admit to sharing a common history and common European destiny. Moreover, in 2017 Jean-Claude Juncker said that stability and security in the EU could only be ensured by the accession of the Western Balkans countries. And reorientation of the Balkan countries towards the standards and practices of the European Union was a reliable fact for the remaining representatives of the EU institutions. In fact, since the early 2000s, the European Union has taken specific steps to integrate the economies and socio-political regimes of these states into its sphere of influence. This boosted the rapid growth of trade turnover ( $80 \%$ increase in comparison to 2016, and over the last five years, the EU has invested more than 10 billion euro in the Balkan countries) and led to various kinds of humanitarian cooperation. The European Union desired to give the impression that Brussels opened the doors to countries of the region willing to join the EU. But after careful consideration of the whole process in general, we can conclude that the European Union pursues a completely different main goal. First, the EU wishes to strengthen the existing instruments of control and influence on the domestic and foreign policy of the Balkan countries. Secondly, the EU would like to prevent the strengthening of positions held by EU's serious rivals in the Balkans, such as Russia, China, Turkey, and the Arab countries. Thirdly, the EU strives to strengthen collapsed credibility and improve the image of the EU in a geopolitically important region. Therefore, the European External Action Service (EEAS) created in April 2015 a special task force for strategic communications (East StratCom Task Force) to counteract especially the Russian influence in the informational sphere. And in October 2017, the governments of several European countries demanded Federica Mogherini that the EEAS significantly expands its activities in the fight 
against Russian propaganda, especially in Southern Europe and the Western Balkans. Moreover, the promised accession of the applicant countries to the European Union is today seen as a matter of an uncertain future, which in reality depends on a large number of subjective variables, due to which it is impossible to predict the timing for potential accession. Therefore, the countries most-longing for EU membership have found and even successfully tried a number of ways to spur the process of European integration. These include, among other things, overtures to the EU's rivals, and threats of destabilization, and nationalistic narrative contradicting all the European standards, and even demonstrative unwillingness to observe the recommendations of Brussels. All this, of course, provoked the emergence of a new strategy of the European Union, but no one can guarantee that the new campaign will be effective and able to provide more reliable control over the region from Brussels. Speaking about its enlargement, the European Union tries to demonstrate its willingness to implement and disseminate its ideology and governance model. In addition, this enlargement, according to European planners, is expected to push the US to perceive the EU as a more equal partner. In any case, the new European strategy is likely to help the European Union gain some time (Kandel, 2018, p. 18).

\section{INFORMATION AND COMMUNICATION STRATEGY OF THE USA IN THE BALKANS}

Washington's information strategy in the Balkans is determined by a certain concern about the prospects for the US presence in this region and reflects worries about the negative deformation of the perception of America as a world leader and guarantor of European security. Since the 1990s, the Balkans have become an important region in the structure of US foreign policy interests due to their position in terms of geopolitics, transportation, and logistics. On the other hand, it was exactly the place where the United States was able to demonstrate its leadership and strength on the international stage ${ }^{3}$. Today, it is much more difficult to

\footnotetext{
${ }^{3}$ Serbia became the target of this demonstration at least twice - in 1995 and 1999.
} 
apply methods similar to those used twenty years ago: the world has changed, the attitude towards such actions within the United States has changed, and, most importantly, the willingness of the American elites to go in for them has also changed. The present environment does not require the degree of presence and display of force that the United States used in the 1990s. Nevertheless, the desire for domination, which still exists in the minds of many Washington residents, forces the US administration to maintain its already acquired positions, while considering two main threats: in geopolitics and cyber security. In this context, Russia is viewed by the American powers that be and Trump's Administration as the most active and serious player in the "soft power" informational landscape and the main "contributor" hindering the integration of the Balkan countries into the Euro-Atlantic structures. Moreover, the greatest concern is caused by the military-technical cooperation between Russia and Serbia. The US Agency for International Development (USAID) has recently developed a concept to counterforce the malignant influence of the Kremlin, condensed down to three pages. The concept identifies four main areas on which, according to USAID, it is necessary to focus in the fight against Russia in Europe. One area relates to interaction with independent media and countering manipulation of information. The main proposals for this area relate, first of all, to the freedom of the media and are aimed at increasing the ability of the media to deliver reliable information. Secondly, they relate to the training in media literacy and the formation of public demand and demand for high-quality journalism as well as ensuring freedom of the press $^{4}$ (Wiśniewski, 2016). In this sense, the most illustrative was the latest campaign against Russian interference in Montenegro. Recently (for about 8 years), the Western mass media have been actively promoting the thesis that Russia, for which information campaigns have long become a habit, is systematically influencing the media space of the Balkan countries. "The Kremlin's strategy is to form the image of Russia as a great power and powerful ally among the population of these states"

\footnotetext{
${ }^{4}$ Despite the fact that Western countries are trying to monitor all manifestations of "Russian propaganda", they have almost lost sight of Moscow's "Balkan campaign", which showed that the West still has a lot to learn.
} 
as stated in reporting contributed by the Washington Post (Wiśniewski, 2016). The contributors emphasize that the propaganda campaign of the Russian Federation is mainly focused on the Orthodox communities in the Balkans and the Serbs. The key instruments of the information policy of Russia in the region are RT and Sputnik Srbija TV channels, which in every possible way popularise the special relations between Russia and the Slavs. In testimony of these theses, the Washington Post puts forward the assertion that RT and Sputnik regularly refer to the common Slavic history and culture, emphasizing the important role of Russia in the fate of the Balkan countries. These agencies also actively use anti-Western narrative, referring to those events and ideas that find a wide response, especially among the Serbs, for example, the NATO bombing (1999). At the same time, the Western countries are shown in the Russian media as culturally alien to the Serbs and unable to understand the so-called "Slavic exclusivity". Russia is trying not only to build a dialogue with the Balkan countries but also to pull them away from the West, the Washington Post notes. According to polls, many Serbian citizens would like to see their country as an ally of Russia, not European states, as emphasized by the contributor of the article in the Washington Post (Wiśniewski, 2016). Therefore, the key statement in the mainstream of Western media is that the United States and the EU should pay the most attention to the Balkan information policy of the Russian Federation and analyse the experience of its implementation. Until now, Western leaders have failed to develop a convincing concept of the unity of the Balkan states and Europe. As a result, public support for the European Union in these countries began to decline.

\section{CONTROL OF THE INFORMATION SPACE IN THE BALKANS}

Currently, the process of external acquisition of the media of the Balkan states is actively underway. The American private investment fund Kohlberg Kravis Roberts (KKR) has been successfully operating in this region for several years. Its leadership includes a four-star General David Petraeus, who was a director of the CIA in September 2011 November 2012. Under the leadership of Petraeus, a real media empire 
was created in the Balkan region. Prior to leaving military service, Petraeus commanded a multinational force in Iraq (February 2007 September 2008) and was the commander of US and NATO forces in Afghanistan (July 2010 - July 2011). At the end of 2016, Donald Trump considered Petraeus's candidacy for the post of head of American diplomacy, but he chose to stay in KKR, already as a partner. General Petraeus is also a member of the US Council on Foreign Relations and a regular member of the Bilderberg Club meetings (Houzelot, 2018). L'Observatoire des Journalists ${ }^{5}$ presented a detailed investigation into the activities of General David Petraeus. The publication states: "Moving into the business world, the former civil servant immediately showed his worth, expanding the already impressive portfolio of KKR. At that time, back in 2013, the fund channelled its first direct investments in Eastern and Central Europe to purchase the United Group media company (SBB/Telemach). The transaction volume was not disclosed, but it was estimated to exceed EUR 1 bn." The United Group brought together the largest cable and satellite TV operators and key Internet service providers in the former Yugoslavia, covering nearly two million users. Among them were:

- SBB (Serbia Broadband) - Serbia's largest cable TV operator and Internet service provider with 700,000 users;

- Total TV - Serbia's leading satellite TV network covering all six countries of the former Yugoslavia;

- NetTV Plus - the main operator of IPTV;

- Telemach - leading cable TV operator and Internet service provider in Slovenia and Bosnia and Herzegovina (BH);

- United Media - TV channels Sport klub, Cinemania, Ultra, Mini Ultra, Lov i ribolov (hunting and fishing);

- CASMedia - the largest advertising agency on cable and satellite television.

In 2014, the KKR Foundation significantly strengthened its influence in the region. Through the United Group was acquired a controlling stake

\footnotetext{
${ }^{5}$ The French Investigative Association of Journalists belonging to the right-wing of the
} French media. Created in 2012. 
in Montenegro's cable television operator BBM and Grand Production, a giant of the entertainment industry in turbo-folk. Then KKR became a coowner of Blic.rs (Serbia's most popular information website), having bought $49 \%$ of the digital division from Ringier, a Swiss media group. In addition, the foundation launched its own regional television network N1 TV with studios in Belgrade, Sarajevo, and Zagreb, becoming an exclusive partner of CNN. "Through this controversial campaign, the United Group has united TV content production with its distribution," as reported by L'Observatoire des Journalistes (Houzelot, 2018). Subsequently, KKR acquired the Slovenian Tušmobil (2015). This was, perhaps, the first case when a cable TV operator acquired a mobile network operator. In 2017, the fund received the Central European Media Enterprises (CME) business in Croatia and Slovenia, including TV Nova, the most popular channel among the Croats. The evening news program of this channel was the highest-rated program in the country, as well as POR-TV, whose 24ur program is, in fact, the main news program in Slovenia. Simultaneously, the United Group continued to expand its sphere of influence by accessing the landline and mobile telephony market and acquiring its rivals, including BHB Cable TV (Bosnia and Herzegovina), M-kabl (Montenegro), and Ikom (Serbia). The Serbian Media Ownership and Control Report provides specific examples of the lack of transparency in the Serbian media and names the true owners of newspapers, magazines, radio stations, and TV channels. (The Journalists' Association of Serbia, 2015). According to this report, the owners of a major part of the most influential media in Serbia are registered abroad - in Cyprus, Holland, the Cayman Islands, Luxembourg, Germany, Switzerland, etc.

\section{INTERNET CONTROL}

In 2010, the US Army Central Command (CENTCOM), led by General D. Petraeus, announced a competition for so-called virtual management software that allows 50 real users to control and manage 500 virtual users, "without the threat of being detected by a trained enemy" (Fielding, Cobain, 2011). The massive control of the world-wide-web by the Anglo-American intelligence services revealed by Edward Snowden 
was at its peak precisely at the time when D. Petraeus headed the CIA. These are projects such as PRISM (Program for Robotics, Intelligent Sensing and Mechatronics), which provides direct access to the servers of such Internet giants as Google, Facebook, Apple, Microsoft, etc., or MUSCULAR (DS-200B) ${ }^{6}$ and Tempora ${ }^{7}$, directly penetrating fiber-optic cables. The Serbian study "Invisible Infrastructures: Data Flow" (Share Lab, 2015) clearly shows that a significant portion of Internet traffic today passes through providers owned by David Petraeus and his SBB network. Ultimately, it became clear that KKR controls a significant number of Internet companies, including GoDaddy (hosting), Optiv (cybersecurity), First Data (emoney), and Internet service providers of the United Group. Thus, all national traffic in Serbia is now controlled by KKR. One of the owners of KKR, General David Petraeus, plans to continue buying up key media and mobile operators in the Balkans, as he and his partners are most interested in establishing complete control over the Balkan media and mobile communication systems.

\section{NON-GOVERNMENTAL ORGANIZATIONS AS THE MAIN ACTORS OF WESTERN INFORMATION EXPANSION IN THE REGION}

Non-governmental organizations (NGOs), as actors of information expansion today, have a significant impact on the formation of the social and civil environment in the post-Soviet space. At the same time, the activities of many local and international non-governmental organizations cause deep concern and pose a threat to national and regional security. The main source of funding for such organizations is the United States, Great Britain, and other NATO countries. Funding is provided either directly or through private foundations associated with

\footnotetext{
${ }^{6}$ A special computer-tracking program used by the UK Government Communications Center (GCHQ) and the US National Security Agency (NSA).

${ }^{7}$ A secret computer-tracking program was created in 2011 and used by the UK Government Communications Center (GCHQ) in conjunction with the US National Security Agency.
} 
the governments and secret services of these countries. Statistics showed that from 2011 to 2014, non-governmental organizations in Macedonia (USA) invested more than $\$ 16$ million, not to mention the funding from USAID (United States Agency for International Development). These funds were distributed among ninety-six NGOs. Nearly $\$ 2.2$ million has been channelled from the National Endowment for Democracy (NED), and the Soros Foundation has allocated \$12.9 million. Another 938,790 USD was transferred from the accounts of several other organizations. The office of the Soros Foundation, the Open Society-Macedonia Foundation, invested in 2016 alone more than $\$ 5.3$ million in the nongovernmental sector of Macedonia, and in just 20 years of the branch's operation, Soros has invested more than $\$ 100$ million in the Macedonian "democracy" (Zotiev, 2017).

In fact, the activities of many NGOs funded by Western entities often represent interference in the domestic and foreign policy of a specific state. For example, in Bulgaria, during the 2017 presidential elections, some Bulgarian non-governmental organizations sponsored by the Soros Foundation campaigned in the media and called for mass riots if the "wrong candidate" (Rumen Radev) wins. And America for Bulgaria Foundation ("Америка за България") paid Bulgarian national television and the private Bulgarian television station BTV $\$ 30,600$ and $\$ 26,500$, respectively, in order to put a "correct spin" during the coverage of the electoral struggle between Clinton and Trump, that is to the benefit of Clinton (Pshenichnikov, 2017). The Soros Foundation has so closely supervised various NGOs in the Balkans and Eastern Europe and sponsored local media to gain control over the media space that the activities of the Soros Open Society Foundation were almost simultaneously opposed in several countries of Eastern Europe and the Balkans. Soros and his foundation are no longer welcomed in Poland, the Czech Republic, Slovenia, Romania, Macedonia, and Hungary (Rambler News, 2017).

\section{CONCLUSION}

In this situation, one can expect a deepening of a further split in the European Union itself concerning the main Balkan problems, in 
particular, the Paris-Berlin dispute as well as increasing attention to alternative integration projects in the Balkan capitals, including those involving Russia, China, and other world powers. The creation of a Western, primarily American, the infrastructure of information impact in the Balkans is a natural process, which can only be countered by creating our own infrastructure, all the more so because S.V. Lavrov noted that the Russian side is interested in participating in the information space of the Balkan region (Lavrov, 2018). Unfortunately, Russia's think tanks carry out their work in these regions only sporadically, and not enough experts and entities are engaged in this process in contrast to the United States and the European Union. And there they are much more in demand by the state. It is necessary to establish systematic work of expert centres of various profiles, which would constantly keep track of the situation in the regions. In April 2019, the Bulgarian capital hosted the Balkan Dialogue Forum, one of the most successful and popular scientific and educational programs of the Alexander Gorchakov Public Diplomacy Support Fund. The Balkan Dialogue - 2019 started with a roundtable discussion "Mass Media as a Tool of Public Opinion Development and Public Worldview Change in the Balkans". During the discussion, the host of the programs "Deconstruction" and "12+3" on the Bulgarian National Radio Peter Volgin lamented that most of the Russia related content released in the media was openly negative: an authoritarian president, a desire for world domination, and other similar patterns. And this is an indisputable fact. At the same time, we should keep in mind that the Western media have recently been losing their reputation as an example of honest and professional journalism. Everything that was previously proclaimed in the West as a "standard" in the work of the media, namely pluralism of opinions, the so-called "second opinion", work with facts, rejection of censorship, is now almost completely lost. The information realm of the West is now predominated not only by intolerance to other opinions and someone else's position, but also direct restrictions on the activities of competing media. The same applies to what is happening on the world's social networks such as Facebook and Twitter. The consequence is the loss of public confidence in journalists. According to the data coming from various sources, one could conclude that the 
situation is only getting worse ${ }^{8}$. During the above-mentioned forum in Bulgaria, the chairman of the Union of Journalists of Bulgaria, Snezhana Todorova, noted in her speech that the country faces serious problems in terms of freedom of speech. The media very strictly adhere to the instructions of the EU and NATO, working off their funding, demonizing Russia. And almost nothing is written about Russia's success in one area or another, about what ordinary people are concerned about. On the other hand, the volume of Euro-Atlantic publications has grown 16 times over the past four years. Nevertheless, $S$. Todorova shared the data of sociological research, showing that about $75 \%$ of Bulgarians consider Russia a friendly country. This suggests that the post-truth being propagated by the Western media mainstream, after all, cannot compete with reality. Therefore, the best way to exert influence by information is not conducting aggressive propaganda, but taking practical joint efforts in the humanitarian sphere and other areas of mutual interest of the parties involved.

\section{References}

In Belgrade, the memory of employees of the RTS TV company - victims of NATO bombing. (2016, April 23), retrieved from https://tass.ru/ mezhdunarodnaya-panorama/3233994. Accessed 6 December 2019.

Strategy for the Western Balkans: the EU launches flagship initiatives and provides support for the region. (2018, February 8), retrieved from https://eeas.europa.eu/headquarters/headquarters-homepage/ 39580/node/39580_ru. Accessed 25 October 2019.

EU: Suzbiti rusku propagandu na zapadnom Balkanu. (2017, October 24), retrieved from http://balkans.aljazeera.net/vijesti/eu-suzbitirusku-propagandu-na-zapadnom-balkanu. Accessed 10 December 2019.

${ }^{8}$ For example, in Russia, $82 \%$ of respondents agree with the opinion, deliberately sharply pointed in the question, that criticism of Vladimir Putin's actions and the situation in Russia in foreign media is an attempt to destroy and destroy our country. 
Kandel P.E. (2018). What's new in EU strategies in the Western Balkans? Contemporary Europe. No. 5. - p. 17-24. doi: 10.15211/soveurope 520181724

COUNTERING MALIGN KREMLIN INFLUENCE (CMKI) DEVELOPMENT FRAMEWORK, retrieved from https://www.usaid.gov/sites/default/files/documents/1863/CMK I_Development_Framework_.pdf . Accessed 22 December 2019.

Wiśniewski, J. (2016, September 19). Russia has a years-long plot to influence Balkan politics. The U.S. can learn a lot from it. Washington Post, retrieved from https://www.washingtonpost.com/news/ monkey-cage/wp/2016/09/19/heres-how-russias-trying-to-swayopinion-in-serbia-and-the-balkans/ . Accessed 23 October 2019.

Houzelot, P. (2018, April 10). David Petraeus - ex - CIA chief, new media mogul in Eastern Europe. The complete investigation. Observatoire du journalisme, retrieved from https://www.ojim.fr/version-russedavid-petraeus-ex-chef-de-cia-nouveau-magnat-medias-europe-delest-lenquete-complete/. Accessed 23 October 2019.

The Journalists' Association of Serbia (2015). ИЗВЕШТАЈ 0 ВЛАСНИЧКОЈ СТРУКТУРИ И КОНТРОЛИ МЕДИЈА У СРБИЈИ, retrieved from http://www.uns.org.rs/sw4i/download/files/article /izvestaj\%20mediji\%2026\%2002.pdf?id=375. Accessed 23 October 2019.

Fielding, N., Cobain, J. (2011, March 11). Revealed: US spy operation that manipulates social media. The Guardian, retrieved from https:// www.theguardian.com/technology/2011/mar/17/us-spy-operation -social-networks. Accessed 18 October 2019.

Share Lab (2015 March 7). Invisible Infrastructures: Data Flow, retrieved from https://labs.rs/sr/nevidljiva-infrastruktura-tokovi-podataka/. Accessed 18 October 2019.

Zotiev, A. (2017, March). Macedonian campaign of George Soros, retrieved from https://cont.ws/@azovchanin77/550227. Accessed 10 October 2019.

Pshenichnikov, I. (2017, January 17). Who is preparing "Maidan" in Bulgaria, retrieved from https://riss.ru/smi/38306/. Accessed 10 August 2020. 
Rambler News (2017). "Soros, go home": sponsor of "color" revolutions lost support of the state Department, retrieved from https://news. rambler.ru/world/36374025-soros-go-home-sponsor-tsvetnyhrevolyutsiy-poteryal-podderzhku-gosdepa/. Accessed 18 August 2020.

Russian top diplomat comments on US, EU policy in Balkans. (2018, February 19), retrieved from https://tass.com/politics/990717. Accessed 27 August 2020. 